\title{
HYPOXIA ENHANCES TRANSCYTOSIS IN INTESTINAL ENTEROCYTES
}

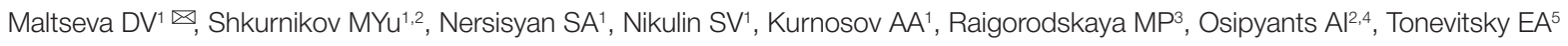

${ }^{1}$ National Research University Higher School of Economics, Moscow, Russia

${ }^{2}$ Hertsen Moscow Oncology Research Center, Moscow, Russia

${ }^{3}$ SRC Bioclinicum, Moscow, Russia

${ }^{4}$ Far Eastern Federal University, Vladivostok, Russia

${ }^{5}$ Fund for Development of Innovative Scientific-Technological Center Mendeleev Valley, Moscow, Russia

The integrity of the intestinal epithelial cell lining is crucial for the normal intestinal function. As a rule, intestinal inflammation is associated with additional tissue hypoxia, leading to the loss of epithelial monolayer integrity. However, in the absence of visible damage to the epithelium, there still might be a risk of infection driven by changes in the intracellular transport of bacteria-containing vesicles. The aim of this study was to investigate the effects of hypoxia on transcytosis using a human intestinal enterocyte model. We found that hypoxia enhances transcytosis of the model protein ricin 1.8-fold. The comparative transcriptome and proteome analyses revealed significant changes in the expression of genes involved in intracellular vesicle transport. Specifically, the expression of apoB (the regulator of lipid metabolism) was changed at both protein (6.5-fold) and mRNA (2.1-fold) levels. Further research is needed into the possible mechanism regulating gene expression in intestinal erythrocytes under hypoxic conditions.

Keywords: hypoxia, enterocyte, intestinal epithelium, microRNA, mRNA, proteome, transcriptome, transcytosis, Caco-2

Funding: the study received public financial support from the Ministry of Science and Higher Education of the Russian Federation (project ID RFMEFI60519X0184).

Acknowledgement: the authors thank the Human Proteome Core Facility (Institute of Biomedical Chemistry) for permission to use the Facility's equipment

Author contribution: Maltseva DV - molecular tests, analysis of their results, manuscript preparation; Shkurnikov MYu - analysis of transcriptome and sequencing data, statistical analysis; Nersisyan SA — sequencing data processing, bioinformatic analysis, functional gene analysis; Nikulin SV — cell culture, sample preparation for subsequent proteome analysis, proteomic data analysis; Kurnosov AA — sample preparation for microRNA sequencing, analysis of sequencing data; Raigorodskaya MP — real-time PCR-based analysis of gene expression, transcriptome analysis; Osipyants Al — cell culture, sample preparation for subsequent proteome and transcriptome analyses; Tonevitsky EA — supervision, data analysis, manuscript preparation.

Compliance with ethical standards: the samples were obtained following the principles of the Declaration of Helsinki.

$\triangle$ Correspondence should be addressed: Diana V. Maltseva

Vavilova, 7, Moscow, 117321; dmaltseva@gmail.com

Received: 08.08.2020 Accepted: 21.08.2020 Published online: 28.08.2020

DOI: $10.24075 /$ brsmu.2020.049

\section{ГИПОКСИЯ УСИЛИВАЕТ ТРАНСЦИТОЗ В ЭНТЕРОЦИТАХ КИШЕЧНИКА}

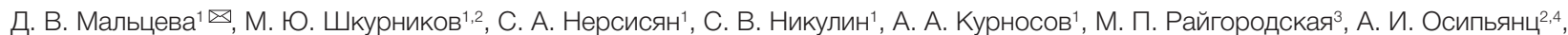
Е. А. Тоневицкий

${ }^{1}$ Национальный исследовательский университет «Высшая школа экономики», Москва, Россия

${ }^{2}$ Онкологический институт имени П. А. Герцена (филиал Национального медицинского исследовательского центра радиологии), Москва, Россия

${ }^{3}$ Научно-технический центр «БиоКлиникум», Москва, Россия

${ }^{4}$ Дальневосточный федеральный университет, Владивосток, Россия

${ }^{5}$ Фонд развития инновационного научно-технологического центра «Долина Менделеева", Москва, Россия

Важнейшее условие нормального функционирования кишечника - сохранение барьерных функций монослоя эпительных клеток, выстилающих его поверхность. Воспалительные состояния кишечника, как правило, ассоциированы с дополнительной тканевой гипоксией, что приводит к нарушению целостности эпителия. Однако опасность инсфекционных заболеваний может сохраняться и при отсутствии очевидных нарушений монослоя клеток. Возможная причина этого - изменение внутриклеточного транспорта везикул, содержащих бактерии. Целью работы было на модели энтероцитов кишечника человека исследовать влияние гипоксии на процесс трансцитоза. Показано, что гипоксия усиливает в 1,8 раза трансцитоз модельного белка, растительного лектина рицина. Сравнительное исследование транскриптомов и протеомов выявило достоверное изменение экспрессии генов, вовлеченных во внутриклеточный везикулярный транспорт, в том числе падение экспрессии регулятора метаболизма липидов ароВ, как на уровне белка (в 6,5 раза), так и на уровне мPHК (в 2,1 раза). Необходимы работы по изучению возможного механизма регуляции экспрессии генов в энтероцитах кишечника в условиях гипоксии.

Ключевые слова: гипоксия, энтероцит, эпителий кишечника, микроРНК, МРНК, протеом, транкриптом, трансцитоз, Сасо-2

Финансирование: работа выполнена при финансовой поддержке государства в лице Минобрнауки России (идентификатор соглашения RFMEFI60519Х0184). Благодарности: авторы благодарят Центр коллективного пользования «Протеом человека» (ИБМХ) за возможность использования оборудования

Вклад авторов: Д. В. Мальцева - молекулярно-биологические исследования, анализ данных, написание статьи; М. Ю. Шкурников - обработка данных транскриптома, секвенирования, статистический анализ; С. А. Нерсисян - обработка данных секвенирования, биоинформатический анализ, функциональный анализ генов; С. В. Никулин - работа с культурой клеток, подготовка образцов для анализа протеома, обработка данных протеома; А. А. Курносов - подготовка образцов для секвенирования микроРНК, анализ данных; М. П. Райгородская - анализ экспрессии генов методом ПЦР-РВ, транскриптомный анализ; А. И. Осипьянц - культуральная работа, подготовка образцов для анализа протеома и транскриптома; Е. А. Тоневицкий организация исследования, анализ данных, написание статьи.

Соблюдение этических стандартов: все образцы для исследования были получены с соблюдением принципов и правил Хельсинской декларации.

$\triangle$ Для корреспонденции: Диана Васильевна Мальцева

ул. Вавилова, д. 7, г. Москва, 117321; dmaltseva@gmail.com

Статья получена: 08.08.2020 Статья принята к печати: 21.08.2020 Опубликована онлайн: 28.08.2020

DOI: 10.24075/vrgmu.2020.049 
Protecting the body against infection and creating a proper environment for commensal bacteria inhabiting the intestine are the central functions of the intestinal epithelium. [1, 2]. Bacteria and their antigens are capable of directly interacting with intestinal epithelial cells, including enterocytes [2, 3]. Such interaction can be broken down into a series of events: binding to the cell surface, endocytosis, exocytosis, and transcytosis of bacteria, their fragments or proteins [3]. Proteins, glycolipids and carbohydrates on the enterocyte surface act as receptors for bacterial pathogens [4]. There is a variety of cell lines used to model bacterial adhesion to the intestinal epithelium [5]. Of them, the most popular is the Caco-2 cell line derived from human colon adenocarcinoma cells [6-8]. In a healthy gut lumen, the hypoxic environment is maintained by the metabolic activity of commensal bacteria [5]. Low oxygen levels stabilize hypoxia-inducible factors $\mathrm{HIF} 1 \alpha$ and $\mathrm{HIF} 2 \alpha$, which, in turn, affect the barrier function of the intestinal epithelium [9]. A lot of intestinal disorders are associated with hypoxia [10]. This underscores the importance of researching the interaction between the intestinal microbiota and the intestinal epithelium under low oxygen conditions.

Plant lectins are well-described proteins that are widely used to study intracellular transport and the binding of proteins to the cell surface $[11,12]$. Glycosylated proteins and lipids act as receptors for plant lectins, making them a suitable model for studying bacterium-cell interactions. The aim of this work was to investigate the effect of hypoxia on transcytosis in intestinal epithelial cells.

\section{METHODS}

Immortalized Caco-2 (colon adenocarcinoma) cells (Institute of Cytology; Saint Petersburg) were cultured in a MEM medium (Gibco; USA) supplemented with 20\% fetal bovine serum (FBS; Gibco; USA), $1 \%(\mathrm{v} / \mathrm{v}$ ) solution of non-essential amino acids (Gibco; USA), $100 \mathrm{un} / \mathrm{ml}$ penicillin, and 100 mg/ml streptomycin (Gibco; USA). The cells were cultured in 6-well plates (Corning; USA) for 23 days until they differentiated into enterocyte-like cells. The medium was replaced every 2-3 days. To induce hypoxia, $300 \mathrm{mM} \mathrm{CoCl}_{2}$ (Sigma-Aldrich; USA) was added to the medium; the resultant mixture was incubated for $24 \mathrm{~h}$. Then, the cells were washed in $1 \times$ DPBS (Gibco; USA) and lyzed for the subsequent transcriptome and proteome analysis as previously described in $[13,14]$.

The effects of hypoxia on the Caco-2 monolayer were evaluated using impedance spectroscopy. Prior to seeding the cells on Transwell ${ }^{\circledR}$-96 permeable supports (Corning; USA), the wells were filled with the culture medium $(50 \mu \mathrm{l}$ in the upper compartment, $235 \mu \mathrm{l}$ in the lower compartment) and incubated for $1 \mathrm{~h}$ at $37{ }^{\circ} \mathrm{C}$ in a $5 \% \mathrm{CO}_{2}$ atmosphere. Then, about 5,600 cells in $50 \mu \mathrm{l}$ medium were seeded in each insert and cultured for 23 days until they differentiated into enterocyte-like cells. The medium was replaced every 2-3 days. To induce hypoxia, $\mathrm{CoCl} 2$ was added to the medium as described above.

Impedance spectra were measured at room temperature in the frequency range of 40 to $20,000 \mathrm{~Hz}$ by means of impedance spectrometry (BioClinicum; Russia) using an STX100C96 electrode (World Precision Instruments; USA) [15]. Mean values of cell impedance properties were calculated based on the data obtained from 3 independent inserts. The membrane surface area in each well was $0.143 \mathrm{~cm}^{2}$. The data were processed using a graphical user interface for R 3.5 (R-Tools Technology; USA).

The plant lectin ricin was extracted from the seeds of the castor oil plant Ricinus communis as described in [16,
17]. Biotinylation, analysis of ricin binding to asialofetuin and cytotoxicity tests on target cells were conducted as described in [18-20].

In order to evaluate transcytosis, differentiated Caco-2 cells were co-incubated with the medium containing biotinylated ricin $\left(1 \times 10^{-7} \mathrm{M}\right)$ in Transwell inserts. The protein was added into the upper compartment onto the apical cell membrane. The colonies were harvested from the lower compartment after 1 and $6 \mathrm{~h}$ of incubation for the subsequent immunoassay.

Lectin concentrations in the culture medium were measured using ELISA. Briefly, $100 \mu \mathrm{l}$ of anti-ricin RA999 antibodies $(10 \mu \mathrm{g} / \mathrm{ml}$ in $10 \mathrm{mM}$ phosphate buffered saline (PBS) pH 7.4; Sigma-Aldrich; Germany) was immobilized on each well of a 96-well plate (Corning; USA) by passive adsorption. Unbound antibodies were removed by washing the wells in PBS containing 0.05\% Tween-20 (PBST). To reduce nonspecific binding, the wells were blocked with PBST containing $0.1 \%$ bovine serum albumin (BSA) (DiaM; Russia). Culture media were diluted 100 -fold in PBST supplemented with $50 \mathrm{mM}$ $\beta$-lactose (Sigma-Aldrich; Germany) and added into the wells (100 $\mu \mathrm{l}$ per well) containing the immobilized antibodies. The resultant mixtures were incubated at $+37^{\circ} \mathrm{C}$ in a thermal shaker. Detection of biotinylated lectin was carried out using HRP-conjugated streptavidin (Intitrogen; Germany). The antibodies were incubated in a 3,3',5,5'-tetramethylbenzidine liquid substrate (Intitrogen; Germany); the reaction was stopped with $1 \mathrm{M} \mathrm{HCl}$ solution. Absorbance was measured at $450 \mathrm{~nm}$ wavelength using a SpectroMax i3 microplate reader (Molecular Devices; USA). Monoclonal antibodies were a gift from Professor Sveshnikov PG (Laboratory of Biotechnology, Russian Research Center for Molecular Diagnostics and Therapy; Russia).

Real-time PCR-based analysis of gene expression was performed as previously described [14]. Transcripts of the $A C T B$ and $G A P D H$ genes were used as references.

mRNA expression profiles were analyzed using Gene Chip Human Transcriptome Array 2.0 (TermoFisher ScientificAffymetrix; USA). RNA isolation, quantification and quality control were performed as described in [14]. The RNA integrity number (RIN) was above 9.5 for all studied samples. cDNA was synthesized from $500 \mathrm{ng}$ of isolated total RNA. All stages of sample preparation, hybridization, washing, staining, and microarray scanning were carried out as described in [21]. CEL files generated by the scanner were processed in Transcriptome Analysis Console 2.0 (TermoFisher Scientific-Affymetrix; USA). Unannotated microarray probesets were excluded from the analysis. The microarray intensity signal equal to 6.0 on the Affymetrix log scale was used as a threshold.

MicroRNA expression profiles were analyzed by means of next-generation sequencing (NGS). NGS libraries were prepared from a small RNA fraction using a CATS small RNAseq kit (Diagenode; Belgium) following the manufacturer's protocol. Upon PCR amplification, the libraries were purified using magnetic AMPPure beads. Final libraries concentrations were measured using a Qubit v2.0 DNA High Sensitivity DNA Kit (TermoFisher Scientific; USA). The pooled libraries were denatured, grouped on 6 Illumina HiSeq2000 V4 flow cell systems (Illumina; USA) and then sequenced. Fifty-one cycles of deep sequencing and 6 index read cycles were run. Sequencing data were exported into a FASTQ file; adapters were trimmed and poly-A-tails were removed from the reads.

Quality control of FASTQ files generated by microRNA sequencing was carried out in FastQC v0.11.9 (Babraham Bioinformatics; UK). Adapter sequences were trimmed in Cutadapt v. 2.8 [22]; reads shorter than 18 nucleotides were 
removed. MicroRNA expression was quantified in miRDeep2 [23]. Differential expression analysis of the microRNA sequencing data was conducted using the $R$ environment $v$. 3.6.3 (R-Tools Technology; USA) and the DESeq2 library [24].

For statistical analysis, the raw data from microarrays were normalized in the oligo software package for $\mathrm{R}$ (R-Tools Technology; USA). Base 2 logarithm was applied to the normalized data. Differential gene and microRNA expression was analyzed using Student's t test. False Discovery Rate (FDR) and the Benjamini-Hochberg procedure were applied for multiple testing correction.

The functional annotation of genes was performed using DAVID databases and algorithms v. 6.8 (Laboratory of Human Retrovirology and Immunoinformatics; USA). Validated microRNA: gene interactions were exported from the DIANATarBase database v. 8 (DIANA Lab; Greece) [25]. microRNA binding sites on 3 '-non-translated regions of mRNA targets were predicted using miRWalk [26]. The search for intronic microRNA and their host genes was conducted in the miRIAD database.

Preparation of Caco-2 lysates, total protein extraction, hydrolytic cleavage and subsequent procedures necessary for proteomic analysis were carried out as described in [14]. After tryptic hydrolysis, the supernatant was collected and analyzed in a Q-Exactive HFX mass spectrometer in the positive ion mode using a nano-spray ion (nESI) source (Thermo Fisher Scientific; USA) operated at the emitter voltage of $2.1 \mathrm{kV}$ and the inlet capillary temperature of $240{ }^{\circ} \mathrm{C}$. For the analysis of differentially expressed proteins, primary spectrometry data were processed in MaxQuant 1.6 (the iBAQ algorithm) (Max-

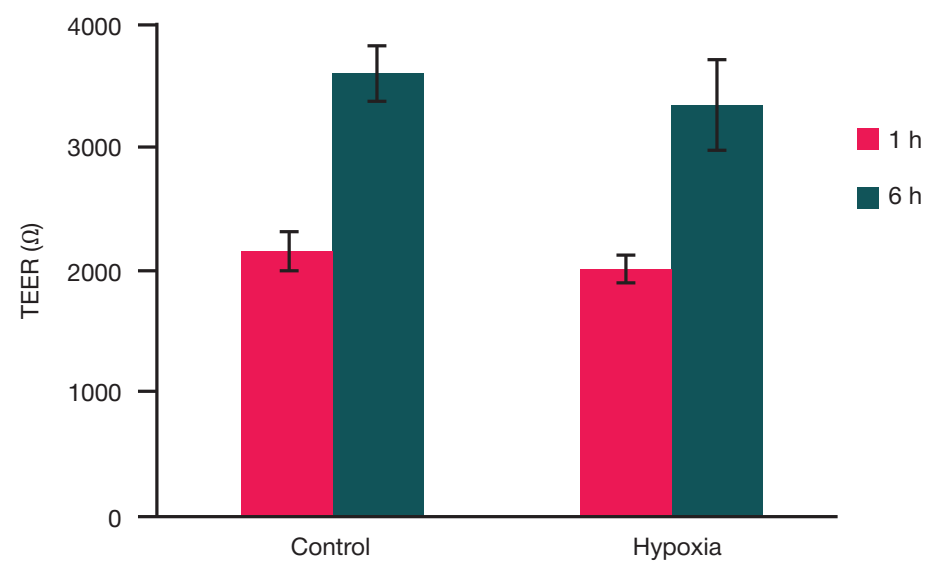

Fig. 1. Transepithelial electrical resistance (TEER) at different time points following the treatment of enterocytes with ricin

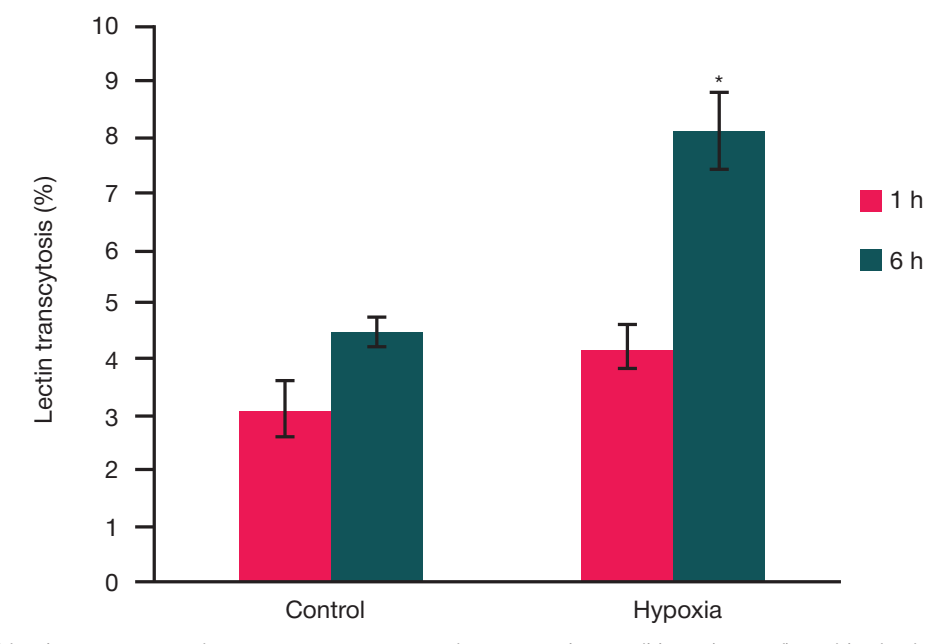

Fig. 2. The amount of biotinylated lectin transcytosed across enterocytes under normoxic conditions (control) and in the hypoxic environment; * - lectin proportion transcytosed after $6 \mathrm{~h}$ under hypoxic conditions differs significantly from the control $(p<0,05)$
Planck-Institute of Biochemistry; Germany). Further data processing was aided by the Perseus platform and R 3.5 with the integrated RStudio 1.1 development environment (R-Tools Technology; USA). Significance of differences was evaluated using Student's t-test.

\section{RESULTS}

\section{Hypoxic culture conditions stimulate transcytosis across intestinal enterocytes and are associated with changed expression of genes involved in vesicle transport}

Caco-2 human colon adenocarcinoma cells were cultured under hypoxia-mimicking conditions created by treating the cells with $\mathrm{CoCl}_{2}$. According to the impedance spectroscopy data, $\mathrm{CoCl}_{2}$ did not disrupt the integrity of the Caco-2 monolayer. The transepithelial electrical resistance (TEER) value remained at 2,000 ' $\Omega$, indicating the lack of pronounced cytotoxicity and cell death.

The microarray analysis of mRNA profiles exposed that treating enterocytes with $\mathrm{CoCl}_{2}$ caused upwards of a twofold increase (FDR < 0.05) in the expression of 165 genes, among which were genes involved in cellular response to hypoxia, such as DDIT4 (2.4-fold), EGLN1 (2.7-fold), LDHA (twofold), PFKFB3 (2.1-fold), SLC2A1 (3.1-fold), SLC2A3 (3.0-fold), and VEGFA (1.4-fold). Changes in the expression profiles of these genes were confirmed by real-time PCR $(p<0.05)$. Besides, the functional annotation of differentially expressed genes assisted by DAVID tools revealed significant enrichment of the 
HIF-1 signaling pathway, which is known to mediate cellular response to hypoxia (this data is not provided in the present study). Summing up, treatment of enterocytes with $\mathrm{CoCl}_{2}$ reliably mimics low-oxygen conditions.

To assess the efficacy of transcytosis across the monolayer of enterocytes under normoxic and hypoxic conditions, the apical domain of the differentiated Caco-2 cells grown in Transwell inserts was treated with the culture medium supplemented with biotinylated ricin. In the control wells, where the cells were cultured under normoxic conditions, the medium in the apical compartment was replaced with lectin-free medium. At 1 and 6 hours after the culture medium in the upper compartment was replaced, the medium from the lower compartment was harvested and analyzed for lectin concentrations using ELISA Cell impedance properties were monitored for $6 \mathrm{~h}$ after lectin treatment; impedance spectroscopy data suggested that integrity of the monolayer was retained, which is consistent with earlier findings [27]. Six hours after lectin treatment, the TEER value increased in both control and hypoxic samples (Fig.10). This suggests formation of more intimate contacts between the cells. Thus, we can rule out the possibility of protein molecules being transported from the upper compartment containing the enterocyte monolayer into the lower compartment via paracytosis. Therefore, lectin was transported from the upper compartment to the lower by means of transcytosis.
According to ELISA, lectin undergoes transcytosis across enterocytes under both normoxic and hypoxic conditions. The amount of transcytosed lectin increased 1.8-fold $(p<0.05)$ after $6 \mathrm{~h}$ in the hypoxic environment, as compared with normoxic conditions (Fig. 2).

The functional analysis of differentially expressed genes allowed us to identify 16 genes involved in the intracellular vesicular traffic (Table 1).

Gene expression profiles of enterocytes were also analyzed by means of protein mass spectrometry. The total number of reliably detected proteins was 3,361. Levels of 237 proteins differed significantly ( $\geq$ two-fold) between the samples cultured under normal and hypoxic conditions. Of all proteins with changed expression profiles (according to microarray data) that were encoded by the genes involved in the intercellular transport of vesicles, only 4 were detected in the proteome: apoB (APOB), SorLA-1 (SORL1), CAM-PRP (PPP3CA), and CEACAM1. A significant (6.5-fold) drop in protein expression was observed for apoB, which is consistent with the results of the transcriptome analysis.

\section{Expression of APOB, SORL1, PPP3CA, and CEACAM1} genes in intestinal enterocytes can be regulated by miRNA

In order to identify a possible mechanism regulating the expression of genes involved in intracellular transport of

Table 1. Differentially expressed genes involved in intracellular vesicular traffic

\begin{tabular}{|l|c|c|c|}
\hline \multicolumn{1}{|c|}{ Gene } & Changes in expression, fold ${ }^{*}$ & $p$-value & FDR \\
\hline OLR1 & -2.4 & 0.0003 & 0.004 \\
\hline ADM & 2.1 & 0.0007 & 0.006 \\
\hline LRP4 & 1.5 & 0.0014 & 0.008 \\
\hline SORL1 & 1.9 & 0.0044 & 0.019 \\
\hline LDLR & 1.9 & 0.0068 & 0.019 \\
\hline ABCA1 & -2.1 & 0.0056 & 0.024 \\
\hline SDCBP & 1.7 & 0.0097 & 0.029 \\
\hline PPP3CA & -1.6 & 0.0219 & 0.029 \\
\hline APOB & -2.1 & 0.0208 & 0.030 \\
\hline CEACAM1 & 1.8 & 0.0243 & 0.030 \\
\hline ENPP1 & -1.8 & 0.0142 & 0.031 \\
\hline ITGA2 & 3.2 & 0.0203 & 0.034 \\
\hline RAB27B & -1.9 & 0.0201 & 0.037 \\
\hline FCHSD2 & -1.6 & 0.0193 & 0.043 \\
\hline SLC9B2 & -1.5 & 0.0381 & 0.046 \\
\hline KIAA1107 & -1.7 & 0.0434 & \\
\hline
\end{tabular}

Note: * 一 the ratio of expression levels (arbitrary units) under hypoxic conditions to the expression levels under standard culture conditions. The data were gathered from microarrays. A negative value means that the expression of the studied gene decreased.

Table 2. Differentially expressed miRNAs regulating the expression of genes involved in intracellular vesicle transport

\begin{tabular}{|l|c|c|}
\hline \multicolumn{1}{|c|}{ miRNA } & Changes in expression, -fold ${ }^{*}$ & mRNA-target \\
\hline hsa-miR-27a-5p & 1.5 & APOB \\
\hline hsa-miR-1303 & -2.1 & SORL1 \\
\hline hsa-miR-100-5p & -1.8 & SORL1 \\
\hline hsa-miR-4521 & -1.6 & SORL1 \\
\hline hsa-miR-21-3p & 1.7 & PPP3CA \\
\hline hsa-miR-32-3p & -1.6 & CEACAM1 \\
\hline hsa-miR-148a-5p & -1.5 & CEACAM1 \\
\hline
\end{tabular}

Note: * 一 the ratio of expression levels (arbitrary units) under hypoxic conditions to the expression levels under standard culture conditions; the data were generated by NGS. A negative value means that the expression of the studied miRNA decreased. 
vesicles, we analyzed miRNA expression profiles using NGS. Changes in transcript expression were significant $(\geq 1.5$-fold, $p \leq 0.05)$ for 16 miRNAs. Interestingly, 7 of them were regulatory miRNAs for APOB, SORL1, PPP3CA and CEACAM1 [25]. For these miRNAs, the direction of changes anticorrelated with the direction of changes in the expression of the corresponding mRNA targets (Table 2).

\section{DISCUSSION}

A tremendous amount of evidence has been accrued about the mechanisms underlying the intracellular transport of vesicles by studying how ricin penetrates the cell [11]. The binding of this plant lectin to glycosylated proteins on the cell surface induces endocytosis, and ricin is then carried by the vesicles to the Golgi apparatus and endoplasmic reticulum. Thank to ricin, researchers were able to learn a lot about the apical and basolateral intracellular transport and transcytosis in polarized epithelial cells.

Ever more attention is being paid to the role of hypoxia and hypoxia-inducible signaling pathways in the physiology of the intestine and its disorders. The normal microenvironment of the intestinal epithelium is physiologically hypoxic; additional tissue hypoxia is a sign of active inflammation [10]. The integrity of the epithelial cell lining is key to the normal intestinal function [2]. But even in the absence of visible damage to the epithelial monolayer, there still could be a risk of infection due to transcytosis, e.g. the intracellular transport of vesicles containing bacteria $[7,28]$. Our study demonstrates that lectin transcytosis is significantly stimulated in the intact enterocyte monolayer under hypoxic conditions. Comparative transcriptome analysis revealed changes in the expression of genes involved in the intracellular transport of vesicles in the cells cultured in a hypoxic environment. A significant drop in the expression of $A P O B$ (one of such genes) was subsequently confirmed by the proteomic analysis. Notably, the apoB protein is the key regulator of lipid and cholesterol metabolism in enterocytes [29, 30]. Found predominantly in the endoplasmic reticulum, apoB facilitates the packaging of lipids and cholesterol adsorbed from the apical lipid domain into prechylomicrons (apoB-containing particles). As these particles are transported inside membrane vesicles to the Golgi apparatus, they mature into chylomicrons and are then secreted from the basolateral enterocyte domain via exocytosis. In a healthy intestinal enterocyte, apoB-containing particles are formed and secreted continuously [29]. Perhaps, the observed significant decrease in apoB expression can activate compensatory mechanisms underlying the secretion of adsorbed and accumulated lipids and cholesterol; one of such possible mechanisms is transcytosis. Importantly, lipids and cholesterol accumulated in the cell are building blocks for cell membranes. Altogether, this might affect membrane transport in enterocytes.

In order to elucidate the mechanism regulating the observed changes, we analyzed miRNA expression profiles. Interestingly, 7 of 16 miRNAs there were found to be differentially expressed in response to hypoxia, were regulators of differentially expressed genes involved in intracellular vesicle transport. Besides, the direction of miRNA expression changes anticorrelated with changes in the expression of the corresponding mRNA-targets. Our findings suggest that enterocyte properties could be altered via a miRNAdependent mechanism under hypoxic conditions.

\section{CONCLUSION}

Using the human intestinal enterocyte model, we demonstrated that hypoxia stimulates transcytosis. This process is accompanied by changes in the expression of genes involved in intracellular vesicle transport. We found that hypoxia is associated with a decrease in the expression of the apoB protein, the key regulator of lipid metabolism at both mRNA and protein levels. The regulatory mechanism underlying changes of cell properties might involve regulation of gene expression by microRNA. Further research into the links between lipid metabolism and transcytosis would help in designing drugs for reducing the risk of intestinal infection promoted by inflammation.

\section{References}

1. Chang C-S, Kao C-Y. Current understanding of the gut microbiota shaping mechanisms. J Biomed Sci. 2019; 26 (1): 59.

2. Solis AG, Klapholz M, Zhao J, Levy M. The bidirectional nature of microbiome-epithelial cell interactions. Curr Opin Microbiol. Elsevier Current Trends. 2020; 56: 45-51.

3. Hu L, Tall BD, Curtis SK, Kopecko DJ. Enhanced microscopic definition of Campylobacter jejuni 81-176 adherence to, invasion of, translocation across, and exocytosis from polarized human intestinal Caco-2 cells. Infect Immun. American Society for Microbiology Journals. 2008; 76 (11): 5294-304.

4. Blanco LP, DiRita VJ. Bacterial-associated cholera toxin and GM1 binding are required for transcytosis of classical biotype Vibrio cholerae through an in vitro $\mathrm{M}$ cell model system. Cell Microbiol. 2006; 8 (6): 982-98.

5. Bartfeld S. Modeling infectious diseases and host-microbe interactions in gastrointestinal organoids. Dev Biol Academic Press. 2016; 420 (2): 262-70.

6. Sakharov D, Maltseva D, Knyazev E, Nikulin S, Poloznikov A, Shilin S, et al. Towards embedding Caco-2 model of gut interface in a microfluidic device to enable multi-organ models for systems biology. BMC Syst Biol BioMed Central. 2019; 13 (S1): 19.

7. Panigrahi P, Bamford P, Horvath K, Morris JG, Gewolb $\Vdash H$. Escherichia coli transcytosis in a Caco-2 cell model: implications in neonatal necrotizing enterocolitis. Pediatr Res Nature Publishing

Group. 1996; 40 (3): 415-21.

8. Rubio APD, Martínez J, Palavecino M, Fuentes F, López CMS, Marcilla A, et al. Transcytosis of Bacillus subtilis extracellular vesicles through an in vitro intestinal epithelial cell model. Sci Rep Nature Publishing Group. 2020; 10 (1): 3120.

9. Kelly CJ, Zheng L, Campbell EL, Saeedi B, Scholz CC, Bayless AJ, et al. Crosstalk between microbiota-derived short-chain fatty acids and intestinal epithelial HIF augments tissue barrier function. Cell Host Microbe. 2015; 17 (5): 662-71.

10. Cummins EP, Crean D. Hypoxia and inflammatory bowel disease. Microbes Infect. 2017; 19 (3): 210-21.

11. Sandvig K, Torgersen ML, Engedal N, Skotland T, Iversen T-G. Protein toxins from plants and bacteria: Probes for intracellular transport and tools in medicine. FEBS Lett. John Wiley \& Sons, Ltd. 2010; 584 (12): 2626-34.

12. Moisenovich M, Tonevitsky A, Agapov I, Niwa H, Schewe $H$, Bereiter-Hahn J. Differences in endocytosis and intracellular sorting of ricin and viscumin in 3T3 cells. Eur J Cell Biol. 2002; 81 (10): 529-38.

13. Khaustova NA, Maltseva DV, Oliveira-Ferrer L, Stürken C, MildeLangosch K, Makarova JA, et al. Selectin-independent adhesion during ovarian cancer metastasis. Biochimie. 2017; 142: 197-206.

14. Maltseva D, Raygorodskaya M, Knyazev E, Zgoda V, Tikhonova O, Zaidi $S$, et al. Knockdown of the $\alpha 5$ laminin chain affects 
differentiation of colorectal cancer cells and their sensitivity to chemotherapy. Biochimie. 2020; 174: 107-16.

15. Gerasimenko T, Nikulin S, Zakharova G, Poloznikov A, Petrov V, Baranova A, et al. Impedance spectroscopy as a tool for monitoring performance in 3D models of epithelial tissues. Front Bioeng Biotechnol. 2020; 7: 474.

16. Tonevitsky AG, Agapov II, Shamshiev AT, Temyakov DE, Pohl P, Kirpichnikov MP. Immunotoxins containing A-chain of mistletoe lectin I are more active than immunotoxins with ricin A-chain. FEBS Lett. 1996; 392 (2): 166-8.

17. Moisenovich M, Tonevitsky A, Maljuchenko N, Kozlovskaya N, Agapov I, Volknandt W, et al. Endosomal ricin transport: involvement of Rab4- and Rab5-positive compartments. Histochem Cell Biol. 2004; 121 (6): 429-39.

18. Agapov II, Tonevitsky AG, Moysenovich MM, Maluchenko NV, Weyhenmeyer R, Kirpichnikov MP. Mistletoe lectin dissociates into catalytic and binding subunits before translocation across the membrane to the cytoplasm. FEBS Lett. 1999; 452 (3): 211-4.

19. Agapov II, Tonevitsky AG, Maluchenko NV, Moisenovich MM, Bulah YS, Kirpichnikov MP. Mistletoe lectin A-chain unfolds during the intracellular transport. FEBS Lett. 1999; 464 (1-2): 63-6.

20. Pohl P, Antonenko YN, Evtodienko VY, Pohl EE, Saparov SM, Agapov II, et al. Membrane fusion mediated by ricin and viscumin. Biochim Biophys Acta. 1998; 1371 (1): 11-6.

21. Kudriaeva A, Galatenko V, Maltseva D, Khaustova N, Kuzina E, Tonevitsky A, et al. The transcriptome of type I murine astrocytes under interferon-Gamma exposure and remyelination stimulus. Molecules. 2017; 22 (5): 808.

22. Martin M. Cutadapt removes adapter sequences from high- throughput sequencing reads. EMBnet.journal. 2011; 17 (1): 10.

23. Friedländer MR, Mackowiak SD, Li N, Chen W, Rajewsky N. miRDeep2 accurately identifies known and hundreds of novel microRNA genes in seven animal clades. Nucleic Acids Res. 2012; 40 (1): 37-52.

24. Love Ml, Huber W, Anders S. Moderated estimation of fold change and dispersion for RNA-seq data with DESeq2. Genome Biol. 2014; 15 (12): 550.

25. Karagkouni D, Paraskevopoulou MD, Chatzopoulos S, Vlachos IS, Tastsoglou S, Kanellos I, et al. DIANA-TarBase v8: a decade-long collection of experimentally supported miRNA-gene interactions. Nucleic Acids Res. 2018; 46 (D1): D239-45.

26. Sticht C, De La Torre C, Parveen A, Gretz N. miRWalk: An online resource for prediction of microRNA binding sites. PLoS One. 2018; 13 (10): e0206239.

27. Flora AD, Teel LD, Smith MA, Sinclair JF, Melton-Celsa AR, O'Brien AD. Ricin crosses polarized human intestinal cells and intestines of ricin-gavaged mice without evident damage and then disseminates to mouse kidneys. PLoS One. 2013; 8 (7): e69706.

28. Macutkiewicz C, Carlson G, Clark E, Dobrindt U, Roberts I, Warhurst G. Characterisation of Escherichia coli strains involved in transcytosis across gut epithelial cells exposed to metabolic and inflammatory stress. Microbes Infect. 2008; 10 (4): 424-31.

29. Ko C-W, Qu J, Black DD, Tso P. Regulation of intestinal lipid metabolism: current concepts and relevance to disease. Nat Rev Gastroenterol Hepatol. 2020; 17 (3): 169-83.

30. Lo CC, Coschigano KT. ApoB48 as an efficient regulator of intestinal lipid transport. Front Physiol. 2020; 11: 796.

\section{Литература}

1. Chang C-S, Kao C-Y. Current understanding of the gut microbiota shaping mechanisms. J Biomed Sci. 2019; 26 (1): 59.

2. Solis AG, Klapholz M, Zhao J, Levy M. The bidirectional nature of microbiome-epithelial cell interactions. Curr Opin Microbiol. Elsevier Current Trends. 2020; 56: 45-51.

3. Hu L, Tall BD, Curtis SK, Kopecko DJ. Enhanced microscopic definition of Campylobacter jejuni 81-176 adherence to, invasion of, translocation across, and exocytosis from polarized human intestinal Caco-2 cells. Infect Immun. American Society for Microbiology Journals. 2008; 76 (11): 5294-304.

4. Blanco LP, DiRita VJ. Bacterial-associated cholera toxin and GM1 binding are required for transcytosis of classical biotype Vibrio cholerae through an in vitro $\mathrm{M}$ cell model system. Cell Microbiol. 2006; 8 (6): 982-98.

5. Bartfeld S. Modeling infectious diseases and host-microbe interactions in gastrointestinal organoids. Dev Biol Academic Press. 2016; 420 (2): 262-70.

6. Sakharov D, Maltseva D, Knyazev E, Nikulin S, Poloznikov A, Shilin S, et al. Towards embedding Caco-2 model of gut interface in a microfluidic device to enable multi-organ models for systems biology. BMC Syst Biol BioMed Central. 2019; 13 (S1): 19.

7. Panigrahi $P$, Bamford $P$, Horvath $K$, Morris JG, Gewolb $I H$. Escherichia coli transcytosis in a Caco-2 cell model: implications in neonatal necrotizing enterocolitis. Pediatr Res Nature Publishing Group. 1996; 40 (3): 415-21.

8. Rubio APD, Martínez J, Palavecino M, Fuentes F, López CMS, Marcilla A, et al. Transcytosis of Bacillus subtilis extracellular vesicles through an in vitro intestinal epithelial cell model. Sci Rep Nature Publishing Group. 2020; 10 (1): 3120.

9. Kelly CJ, Zheng L, Campbell EL, Saeedi B, Scholz CC, Bayless AJ, et al. Crosstalk between microbiota-derived short-chain fatty acids and intestinal epithelial HIF augments tissue barrier function. Cell Host Microbe. 2015; 17 (5): 662-71.

10. Cummins EP, Crean D. Hypoxia and inflammatory bowel disease. Microbes Infect. 2017; 19 (3): 210-21.

11. Sandvig K, Torgersen ML, Engedal N, Skotland T, Iversen T-G. Protein toxins from plants and bacteria: Probes for intracellular transport and tools in medicine. FEBS Lett. John Wiley \& Sons, Ltd., 2010; 584 (12): 2626-34.

12. Moisenovich M, Tonevitsky A, Agapov I, Niwa $H$, Schewe $H$, Bereiter-Hahn J. Differences in endocytosis and intracellular sorting of ricin and viscumin in 3T3 cells. Eur J Cell Biol. 2002; 81 (10): 529-38.

13. Khaustova NA, Maltseva DV, Oliveira-Ferrer L, Stürken C, MildeLangosch K, Makarova JA, et al. Selectin-independent adhesion during ovarian cancer metastasis. Biochimie. 2017; 142: 197-206.

14. Maltseva D, Raygorodskaya M, Knyazev E, Zgoda V, Tikhonova O, Zaidi S, et al. Knockdown of the $\alpha 5$ laminin chain affects differentiation of colorectal cancer cells and their sensitivity to chemotherapy. Biochimie. 2020; 174: 107-16.

15. Gerasimenko T, Nikulin S, Zakharova G, Poloznikov A, Petrov V, Baranova A, et al. Impedance spectroscopy as a tool for monitoring performance in 3D models of epithelial tissues. Front Bioeng Biotechnol. 2020; 7: 474

16. Tonevitsky AG, Agapov II, Shamshiev AT, Temyakov DE, Pohl P, Kirpichnikov MP. Immunotoxins containing A-chain of mistletoe lectin I are more active than immunotoxins with ricin A-chain. FEBS Lett. 1996; 392 (2): 166-8.

17. Moisenovich M, Tonevitsky A, Maljuchenko N, Kozlovskaya N, Agapov I, Volknandt W, et al. Endosomal ricin transport: involvement of Rab4- and Rab5-positive compartments. Histochem Cell Biol. 2004; 121 (6): 429-39.

18. Agapov II, Tonevitsky AG, Moysenovich MM, Maluchenko NV, Weyhenmeyer R, Kirpichnikov MP. Mistletoe lectin dissociates into catalytic and binding subunits before translocation across the membrane to the cytoplasm. FEBS Lett. 1999; 452 (3): 211-4.

19. Agapov II, Tonevitsky AG, Maluchenko NV, Moisenovich MM, Bulah YS, Kirpichnikov MP. Mistletoe lectin A-chain unfolds during the intracellular transport. FEBS Lett. 1999; 464 (1-2): 63-6.

20. Pohl P, Antonenko YN, Evtodienko VY, Pohl EE, Saparov SM, Agapov II, et al. Membrane fusion mediated by ricin and viscumin. Biochim Biophys Acta. 1998; 1371 (1): 11-6.

21. Kudriaeva A, Galatenko V, Maltseva D, Khaustova N, Kuzina E, Tonevitsky A, et al. The transcriptome of type I murine astrocytes under interferon-Gamma exposure and remyelination stimulus. Molecules. 2017; 22 (5): 808.

22. Martin M. Cutadapt removes adapter sequences from highthroughput sequencing reads. EMBnet.journal. 2011; 17 (1): 10. 


\section{ORIGINAL RESEARCH I GASTROENTEROLOGY}

23. Friedländer MR, Mackowiak SD, Li N, Chen W, Rajewsky N. miRDeep2 accurately identifies known and hundreds of novel microRNA genes in seven animal clades. Nucleic Acids Res. 2012; 40 (1): 37-52.

24. Love MI, Huber W, Anders S. Moderated estimation of fold change and dispersion for RNA-seq data with DESeq2. Genome Biol. 2014; 15 (12): 550.

25. Karagkouni D, Paraskevopoulou MD, Chatzopoulos S, Vlachos IS, Tastsoglou S, Kanellos I, et al. DIANA-TarBase v8: a decade-long collection of experimentally supported miRNA-gene interactions. Nucleic Acids Res. 2018; 46 (D1): D239-45

26. Sticht C, De La Torre C, Parveen A, Gretz N. miRWalk: An online resource for prediction of microRNA binding sites. PLoS One. 2018; 13 (10): e0206239.
27. Flora AD, Teel LD, Smith MA, Sinclair JF, Melton-Celsa AR, O'Brien AD. Ricin crosses polarized human intestinal cells and intestines of ricin-gavaged mice without evident damage and then disseminates to mouse kidneys. PLoS One. 2013; 8 (7): e69706.

28. Macutkiewicz C, Carlson G, Clark E, Dobrindt U, Roberts I, Warhurst G. Characterisation of Escherichia coli strains involved in transcytosis across gut epithelial cells exposed to metabolic and inflammatory stress. Microbes Infect. 2008; 10 (4): 424-31.

29. Ko C-W, Qu J, Black DD, Tso P. Regulation of intestinal lipid metabolism: current concepts and relevance to disease. Nat Rev Gastroenterol Hepatol. 2020; 17 (3): 169-83.

30. Lo CC, Coschigano KT. ApoB48 as an efficient regulator of intestinal lipid transport. Front Physiol. 2020; 11: 796. 